\title{
Awareness Level of Farm Youth on Information and Communication Technology (ICT) Tools in Tiruvannamalai District of Tamil Nadu
}

\section{Balu* and M. Kavaskar}

Department of Agricultural Extension, Faculty of Agriculture, Annamalai University, Chidambaram, Tamil Nadu, India "Corresponding author: agribalubsc@gmail.com

\begin{abstract}
Indian agriculture is dominated by small and marginal farmers whose education is weak and majority of are often unable to access information that could increase yield for their crop. The government has a huge research and development infrastructure in the form of institutions such as the Indian Council of Agricultural Research (ICAR), Agricultural Universities and Krishi Vigyan Kendra's (KVKs) and other institutes, but today these institutions are facing many constraints in mobility of technological staffs for transfer of technological information at the village level. There has been no significant technology innovation, which could give a fresh impetus to agricultural productivity. Insufficient extension services and poor access to information further widen the gap in the adoption of technology and lead to poor productivity levels; in fact information is critical to the social and economic activities that comprise the development process and right information at right time will play a crucial role for development of Indian agriculture. Here comes the role of ICTs, which are powerful and productive with new ideas, methods of the technology dissemination and further improving the knowledge and information among the society. In recent years, there is visible shift from the old ways to the modern ways of information delivery system. (ICT) has become a powerful tool for improving the delivery service and enhancing local development opportunities. The study was taken up in Tiruvannamalai district of Tamil Nadu. A total sample size of 120 farm youth were selected. The collected data were analysed with the help of SPSS software. The results indicated that majority of the farm youth (56.67 per cent) were aware the ICT tools. The remaining (43.33 per cent) were not aware the ICT tools.
\end{abstract}

Keywords: Awareness Level, Farm Youth, Information and Communication Technology ownership of ICT gadgets

Indian agriculture contributes16 per cent of our GDP and approximately 60 per cent of Indians derive their livelihood from the agricultural sector. The performance of agriculture basically means the performance of small holder farming. It is only by empowering the small and marginal farmers to overcome their handicaps; they can become instruments of evergreen revolution and growth in agricultural sector. The limiting factors of farming in maximizing their farm income are access to technology, government endeavour,

How to cite this article: Balu, D. and Kavaskar, M. (2020). Awareness Level of Farm Youth on Information and Communication Technology (ICT) Tools in Tiruvannamalai District of Tamil Nadu. International Journal of Inclusive Development, 6(02): 87-90.

Source of Support: None; Conflict of Interest: None 
resources, markets, institutions and services. Farming community is facing a lot of problems in maximizing the crop productivity. In spite of successful research on new agriculture practices, majority of farmers are not getting upper bound yield due to several reasons. One of the reasons is that expert scientific advice on crop production and marketing is not reaching their farming community in time. There is a concern that the gap between the information rich and information poor is getting wider.

Generally, farmer follow the advice of local shopkeepers/agents who sells him seeds, fertilizers, insecticides, pesticides, etc. Information and Communication Technology (ICT) is a global term that includes all technologies for the manipulation and communication of information. ICTs are defined as electronic and digital technologies for storing, processing, transferring of information and communication. These are enabling technologies that allow quicker and more efficient exchange and processing of information. During the last two decades, remarkable developments have taken place in information and communication technology (Kavaskar and Sharmila, 2019).

The ICT tools like desktop and laptop computers, tablet PCs, cell phones, smart phones, satellite phone, FM radio; multimedia devices like web camera, digital camera, handy cam, data cards, blue-tooth; storage devices like pen drive, CDROMs and DVDs; information kiosks, touch screen systems, experts systems etc. have been popular for information exchange. Computer and Internet enabled technologies like e-mail e-commerce, e-learning, e-conferencing, Interactive voice response services (IVRS), various type call centers, teleconferencing, video conferencing, computer assessed services, wireless application protocol (WAP) and other online services; mobile enabled services like SMS, MMS, GPRS, web based GIS, remote sensing etc. has been generalized among the people. It is essential to effectively communicate the useful agricultural technologies to the farmers. Improved communication and access to agriculture information are directly related to empowerment of farming community (Sharmila and Kavaskar, 2017). The information need of Indian farmers across the country is varied. Introduction of information and communication technology (ICT) enables the dissemination of the requisites information at the right time. This revolution in information technology has made access to the information easy and cost effective. ICT initiatives still require significant improvements in supporting infrastructure and capacity building amongst farmers to enable them to use the information they access effectively. It was also noted that sources of information had strategic effect on adoption of farm technology; socio-economic factors were interrelated and family size and family types had more impact on others socio-personal variables/factors outcome (Panda, 2014) Fawole (2012) reported that awareness on old ICTs like radio (98.80 per cent) and television (94.70 per cent) was widespread among farmers, few were aware on new ICTs such as mobile phone (80.90 per cent), internet (26.60 per cent), digital video disc (30.40 per cent ) and cable television (25.90 per cent). Moon et al. (2016) reported that two-third (68.00 per cent) of the respondents belonged to medium level of awareness on ICT tools followed by 26.00 per cent and low 6.00 per cent low level of awareness on ICT tools.

\section{METHODOLOGY}

The study was taken up in Tiruvannamalai district of Tamil Nadu. A total sample size of 120 farm youth were selected. A comprehensive interview schedule covering all the aspects of ICT tools was developed. The collected data were analysed with the help of SPSS software. The ownership of ICT gadgets referred to the ICT materials and equipments possessed by the respondents. It was measured by asking the respondents to give the ICT facilities they possessed. For each item, score of ' 1 is given. Summation of the score for the items resulted with the score of the respondents on ownership of ICTs. The awareness of the respondents on the selected ICT tools was classified into two categories namely aware and not aware.

\section{RESULTS AND DISCUSSION}

The findings on awareness of farm youth about various ICT tools are presented in the followed aspects-

1. Awareness about ICT tools

2. ICT tools wise awareness 


\section{Overall awareness about ICT tools}

The distribution of respondents according to their overall awareness about ICT tools are analyzed and furnished in Table 1.

Table 1: Distribution of the respondents according to their overall awareness about ICT tools $(n=120)$

\begin{tabular}{llll}
\hline S1. No. & Awareness & Number & Per cent \\
\hline 1 & Aware & 68 & 56.67 \\
2 & Not aware & 52 & 43.33 \\
\hline Total & & $\mathbf{1 2 0}$ & $\mathbf{1 0 0 . 0 0}$ \\
\hline
\end{tabular}

It could be seen from the Table 1 that majority of the farm youth (56.67 per cent) were aware the ICT tools. The remaining (43.33 per cent) were not aware the ICT tools. It could be concluded that majority of the respondents (56.67 per cent) were aware of the existence of various ICT tools. It may be due to the fact that all the respondents were educated and the advancement in communication technologies shrinks the world in to a global village. It is quite natural and necessary for the agriculture information regarding the communication technologies and make use of the possible technologies having more applicability in transfer of technology process.

\section{ICT tools wise awareness}

It was considered necessary to analyse to tools wise ICT awareness in addition to the overall awareness. Hence in these aspects data collected and presented in Table 2.

Overview of the Table 2, revealed that cent per cent of the farm youth were fully aware about the ICT tools viz., radio, TV and telephone (100.00 per cent) which was followed by the ICT tools namely smart phone (93.33 per cent), social networks (91.66 per cent) facebook, twitter and whatsapp followed by computer (83.33 per cent), internet/ web services (81.66 per cent), MS word (70.83 per cent), web based search engines (58.33 per cent), digital camera (45.83 per cent), agriportals (44.17 per cent), MS excel (44.16 per cent), Kisan Call Centre (42.50 per cent), MS power point (40.83 per cent), E-newspaper (26.66 per cent), expert system (21.66 per cent), video camera (15.83 per cent), video conferencing (12.50 per cent), e-agriculture magazine (15.00 per cent), IMCD (6.66 per cent) and information kiosk (4.16 per cent).
Table 2: Distribution of respondents according to their extent of awareness on ICT Tools $(n=120)$

\begin{tabular}{|c|c|c|c|}
\hline Sl. No. & ICT Tools & Aware & Per cent \\
\hline 1 & Radio & 120 & 100 \\
\hline 2 & Television & 120 & 100 \\
\hline 3 & Telephone & 120 & 100 \\
\hline 4 & Smart phone & 112 & 93.33 \\
\hline 5 & Computer & 100 & 83.33 \\
\hline 6 & Digital Camera & 55 & 45.83 \\
\hline 7 & Video camera & 19 & 15.83 \\
\hline 8 & Video conferencing & 15 & 12.50 \\
\hline 9 & Social networks & 110 & 91.66 \\
\hline 10 & $\mathrm{KCC}$ & 51 & 42.50 \\
\hline 11 & Internet/ web services & 98 & 81.66 \\
\hline 12 & Web based search engines & 70 & 58.33 \\
\hline 13 & Agriportals & 53 & 44.17 \\
\hline 14 & $\begin{array}{l}\text { Interactive Multimedia } \\
\text { Compact Disc (IMCD) }\end{array}$ & 08 & 6.66 \\
\hline 15 & E-newspaper & 32 & 26.66 \\
\hline 16 & e-agricultural magazine & 18 & 15.00 \\
\hline 17 & MS Word & 85 & 70.83 \\
\hline 18 & MS Excel & 53 & 44.16 \\
\hline 19 & MS PowerPoint & 49 & 40.83 \\
\hline 20 & Expert system & 26 & 21.66 \\
\hline 21 & Information kiosk & 05 & 4.16 \\
\hline
\end{tabular}

Hence, it could be concluded that cent per cent of the farm youth had aware the ICT tools viz., (radio, TV and telephone). Thus it could be inferred from the above findings that the farm youth are regularly exposed to the ICT tools through various sources and it was considered necessary to gain awareness about the various ICT tools. It helps to adopt the latest farming technologies. This may be the probable reason for their high level of awareness about various ICT tools.

\section{Ownership of ICT gadgets}

The extension service must be able to provide information that makes differences. ICTs tools help build human network, increase public awareness and provide access to information and knowledge for the use among farm youth. They include phone, radio, $\mathrm{TV}$, internet, computer, laptop and digital camera etc. An attempt has been made to study the ICT gadgets owned by the respondents and the data collected are presented in Table 3. 
c) Balu and Kavaskar

Table 3: Distribution of respondents according to their ownership of ICT gadgets $(n=120)$

\begin{tabular}{llll}
\hline S1. No. & ICT gadgets & Number & Per cent \\
\hline 1 & Computer & 07 & 5.83 \\
2 & Laptop & 38 & 31.66 \\
3 & Smart phone & 112 & 93.33 \\
4 & Telephone & 16 & 13.33 \\
5 & Tablet & 08 & 6.66 \\
6 & TV & 120 & 100.00 \\
7 & Cable connection / DTH & 120 & 100.00 \\
8 & Radio & 110 & 91.66 \\
9 & Digital camera & 31 & 25.83 \\
10 & Handy cam & 02 & 1.66 \\
11 & Earphone & 64 & 53.33 \\
12 & Printer & 03 & 2.50 \\
13 & Scanner & 01 & 0.83 \\
14 & Internet connection & 07 & 5.83 \\
\hline
\end{tabular}

It was found from the Table 3, that cent per cent of respondents had TV and cable connection/ DTH followed by smart phone (93.33 per cent), radio (91.66 per cent), earphone (53.33 per cent), laptop (31.66 per cent), digital camera (25.83 per cent), telephone (13.33 per cent), tablet (6.66 per cent), computer (5.83 per cent), printer (2.50 per cent), handy cam (1.66 per cent) and scanner ( 0.83 per cent). It could be interpreted that due to the advances in digital technology the dissemination of agricultural technologies to the farm youth has become faster than ever before. Many private channels have come to the area for delivering agricultural and related information to its audience. Some of the channels include, Pothigai TV, Pudhiya Thalaimurai and Makkal TV. These channels have attracted a diverse group of audience to view agriculture related programmes and thus many of them are having the latest gadgets like, smart phone, TV, Radio, DTH connection, laptop and earphone.

\section{REFERENCES}

Fawole, O.P and Olajide, B.R. 2012. Awareness and Use of Information Communication Technologies by Farmers in Oyo State, Nigeria. Journal of Agricultural $\mathcal{E}$ Food Information, 13: 326-337.

Kavaskar, M. and Sharmila, A. 2019. Utilization of ICT Tools by the Extension Personnel for Effective Delivery of Farm Information, International Journal of Innovative Technology and Exploring Engineering, 8(11): 113-116.

Panda, C.K. 2014. Information sources and technology adoption by farmers: An empirical study in mohanpur block, West Tripura. International Journal of Extension Education, 10: 80-87.

Moon, S.J., Miah, M.A. M. and Berg, T. 2016. Farmer's Awareness on Effective Delivery of Farm Information through ICT Mediated Extension Service in Bangladesh. European Scientific Journal, 12(21).

Sharmila, A. and Kavaskar, M. 2017. Knowledge Level of Extension Personnel on Information and communication Technology (ICT), Journal of Global Communication, 10(2): 91-95. 